\title{
Effects of Chemicals on the Population of Amblyseius womersleyi ScHICHA (Acari: Phytoseiidae) and Tetranychus kanzawai KISHIDA (Acari: Tetranychidae) When the Tops and the Inside of Tea Bushes Were Sprayed
}

\author{
Akira KAWAI* \\ National Institute of Vegetable and Tea Science, \\ National Agricultural Research Organization
}

\section{Summary}

The effects of chemicals on the population of the predatory mite Amblyseius womersleyi and its prey Tetranychus kanzawai were evaluated when the tops or the inside of tea bushes were sprayed. The population densities of both species were counted from April to November in 1997, and chemicals were sprayed six times during the experiment. The densities of both species in the plot where the tops of the bushes were sprayed were the same as those in the untreated plot. The density of T. kanzawai in the plots where the tops and the inside of the bushes were sprayed was significantly higher than that in the untreated plot. Chemicals sprayed on the plucking surface did not significantly affect the predatory mite population, but spraying inside the leaf layer had significant effects. However, A. womersleyi controlled the population of $T$. kanzawai quite well even in the plot with inside spraying. Since the leaf layer of the tea bushes effectively blocked the penetration of chemicals, the bush below the plucking surface is very important as a refuge for natural enemies.

\section{INTRODUCTION}

Tea plants Camellia sinensis (L.) KUNTZE are developed into a characteristic shape by the plucking and skiffing. The leaves grow thick beneath the plucking surface. When chemicals are sprayed above the plucking surface, the thick leaf layer blocks the penetration of chemicals inside the bush and the deposition at the bottom of layer was only 1 to $2 \%$ of that at the top of layer "'.

In tea fields, the predatory mite Amblyseius womersleyi SCHICHA effectively controls the population density of the Kanzawa spider mite Tetranychus kanzawai KIsHIDA, even under insecticidal control ${ }^{2)}$. In addition, though the population densities of several species of natural enemies (A. womersleyi, Scolothrips takahashii PRIESNER, Agistemus exsertus GoN. ZALEZ and Feltiella sp.) of T. kanzawai were low on leaves near the plucking surfaces of tea plants, they were high on the leaves beneath the plucking surfaces, even under insecticidal control ${ }^{3)}$. This suggests that the leaves beneath the plucking surfaces work as the refuge for these natural enemies against insecticide sprayed above

Accepted; July 13, 2001

* Ano, Mie 514-2392 
the plucking surface. However, the effect of chemical spraying of tea bushes on the population of natural enemies was unknown.

In this study, the effect of insecticide sprayed above or inside of bushes on the population fluctuations of $T$. kanzawai and $A$. womersleyi is examined, and the efficiency of the leaves beneath the plucking surfaces as the refuge for natural enemies against sprayed insecticide is discussed.

\section{MATERIALS AND METHODS}

A population census was done from April to November in 1997 in a tea field at the National Research Institute of Vegetables, Ornamental Plants and Tea (NIVOT), Kanaya Shizuoka, that was planted with a 36-year-old variety of $Y a b u$ kita. The field had eight tea bushes and the area of each bush was $9 \mathrm{~m}^{2}$. These bushes were planted $1 \mathrm{~m}$ apart each other. Three bushes were used as a surface-spraying plot in which chemicals were sprayed only on the plucking surface at the rate of
200 liters per $10 \mathrm{a}$. Another three bushes were used as an inside-spraying plot in which chemicals were sprayed both on and inside the bushes at the rate of 400 liters per $10 \mathrm{a}$. Two bushes were used as an untreated plot. The chemicals used in the two spraying plots (Table 1) were selected same as the conventional control in tea fields of NIVOT and semi-automatic knapsack hand sprayer was used for spraying.

Population densities of $A$. womersleyi and $T$. kanzawai were counted once a week. Fifty mature leaves were collected from the inside of each bush. The num. bers at all stages of both species were counted using a binocular microscope.

\section{RESULTS}

Population fluctuations in the total number of $A$. womersleyi and T. kanzawai in each of the three plots are shown in Fig. 1. The chemicals that were registered against $T$. kanzawai were sprayed twice in the spraying plots. In the first time, the populations of $T$. kanzawai in the sprayed plots were very low at the spraying and

Table 1. Chemicals sprayed in the experimental field.

\begin{tabular}{clcll}
\hline Date & Chemical & $\begin{array}{c}\text { Concentration } \\
(\mathrm{ppm})\end{array}$ & Type $^{1)}$ & Main target pest $^{2)}$ \\
\hline May 19 & Pyraclofos & 350 & OP & Ah, Hm, Tk \\
Jun. 13 & Fenpropathrin & 50 & PY & Sd, Eo, Ct \\
Jul. 14 & Chlorpyrifos & 400 & OP & Ah, Hm \\
Jul. 23 & Imidacloprid & 100 & CH & Sd, Eo, Ct \\
Sep. 4 & Acephate & 500 & OP & Sd, Eo, Ah, Hm \\
Oct. 6 & Prophenofos & 400 & OP & Ah, Hm, Tk, Sd, \\
\hline
\end{tabular}

1) OP: Organophosphorus insecticide, PY: Pyrethroid insecticide,

Ch: Chloronicotinyl insecticide

2) Ah: Adoxophyes honmai YASUDA, Hm: Homona magnanima DIAKONOFF,

Tk: Tetranychus kanzawai KISHIDA, Sd: Scirtothrips dorsalis HOOD,

Eo: Empoasca onukii Matsuda, Ct: Caloptilia theivora (WALSINGHAM),

As: Ascotis selenaria (DENIS et SCHIFFERMULLER) 
increased like as the untreated plot. In the second time, the population in surfacespraying plot decreased a little just after the spraying but increased again from the second week. In the inside-spraying plot, it increased after the spraying. The difference of the effect by the spraying method was not clear. These chemicals had some effect on the population of T. kanzawai, but the effect was not serious.

In the untreated plot, the population of $T$. kanzawai peaked in June and September. After the population of T. kanzawai increased, the population density of $A$. womersleyi also subsequently increased and, consequently, the population of $T$. kanzawai then decreased. The peak densities of T. kanzawai in June and September were 23.0 and 49.0 individuals per 50 leaves, respectively, and the new shoots did not show any evidence of damage by the mite. In the surface-spraying plot, the population of $T$. kanzawai peaked in June and September, and those densities were 17.7 and 69.0 individuals per 50 leaves, respectively, nearly equal to the untreated plot. In the inside-spraying plot, the population of $T$. kanzawai also peaked in June
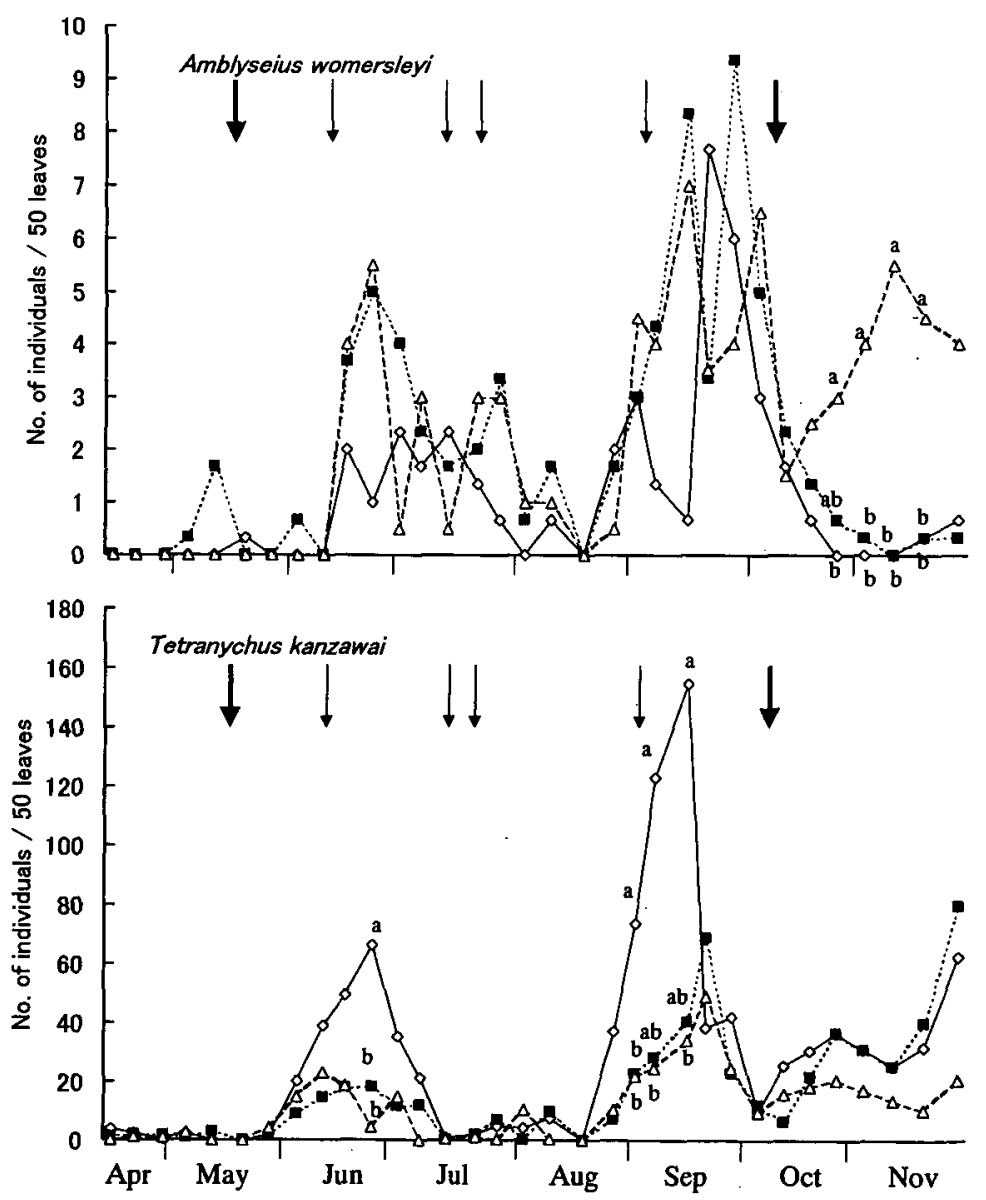

Fig. 1. Population fluctuations in the total number of Amblyseius womersleyi and Tetranychus kanzawai in each of the three plots. Arrows indicate the insecticide spraying, and big ones indicate chemicals that are registered against $T$. kanzawai were sprayed. 


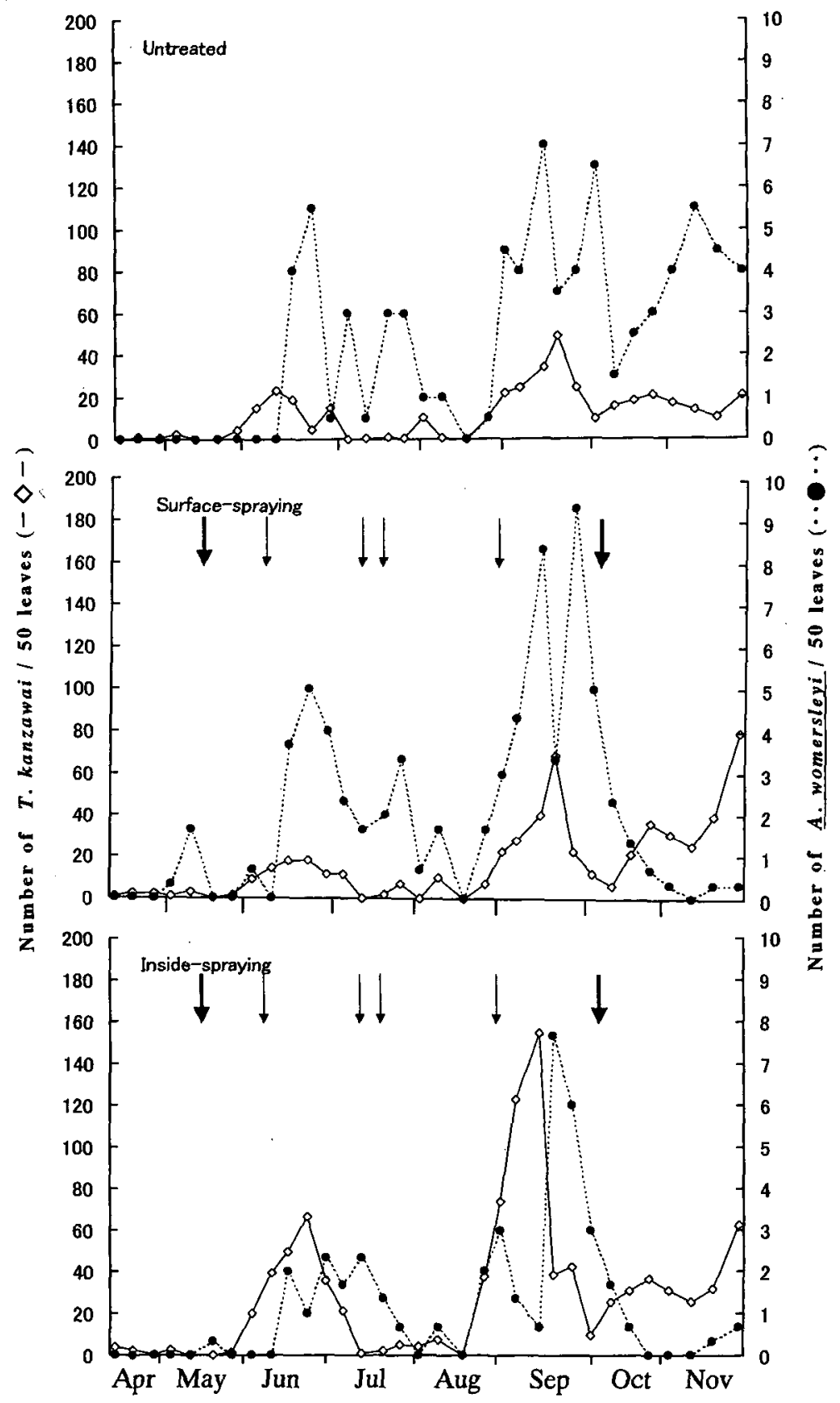

Fig. 2. Comparison of the population densities of Amblyseius womersleyi and Tetranychus kanzawai in the three plots. $\triangle$ : untreated plot, $\mathbf{\square}$ : surface-spraying plot, $\diamond$ : insidespraying plot. Arrows indicate the insecticide spraying, and big ones indicate chemicals that are registered against $T$. kanzawai were sprayed. Symbols with different letters indicate significant difference between plots in Spjotvoll \& Stoline's multiple range test $(P<0.05)$. Symbols without a letter indicate no significant difference in any combination of the plots $(P \geqq 0.05)$. 
and September, and the peak densities were 66.3 and 154.7 individuals per 50 leaves, respectively. The peak densities were much higher than those in the untreated plot, nevertheless the new shoots did not show anyevidence of having been damaged by the mite. In all plots, $A$. womersleyi effectively controlled the population density of $T$. kanzawai.

A comparison of the population densities of $A$. womersleyi and $T$. kanzawai among the three plots is shown in Fig. 2. Significant differences in the population densities of $A$. womersleyi among the three plots were not observed until the middle of October. One peak was observed in late June to July and another in late September to October in all plots. However, the density at the beginning of those peak periods in the inside-spraying plot tended to be lower those that in the other plots. From the end of October to November, the densities in the untreated plot was significantly higher than those in the other two plots $(P<0.05)$. Significant differences in the population density of $T$. kanzawai between the untreated and surface-spraying plots were rarely observed throughout the census period. On the contrary, the peak densities in the inside-spraying plot were significantly higher than those in the other two plots $(P<0.05)$. This difference was much more prominent in the second peak.

\section{DISCUSSION}

The population fluctuations of $T$. kanzawai and $A$. womersleyi were examined in a tea field. Various species are already known as the natural enemy of T. kanzawai. However, since the density of other natural enemies was very low in the census field, $A$. womersleyi mainly affected the population fluctuation of $T$. kanzawai.

The densities of $A$. womersleyi and $T$. kanzawai were not significantly different between the untreated and surfacespraying plots (Fig. 2). Since the deposition of chemicals inside the bushes by spraying on the leaf layer was small ${ }^{11}$, chemicals sprayed on the leaf layer did not noticeably affect the population of $A$. womersleyi in the bushes. On the contrary, the density of $T$. kanzawai in the insidespraying plot was higher than those for other plots, and the density of $A$. womersleyi tended to be low at the beginning of the peaks (Fig. 2). The harmful effects of chemicals ${ }^{2,4)}$ sprayed directly inside the bushes probably decreased the population of $A$. womersleyi and increased that of $T$. kanzawai.

A. womersleyi in tea fields in Shizuoka Prefecture is known to have developed resistance against many kinds of insecticide, i.e. organophosphorus, carbamate, and pyrethroid insecticides ${ }^{5 \sim 7)}$. Though susceptibility of $A$. womersley $i$ in the experimental field against the sprayed chemicals was not examined, the population supposed to be resistant to various kinds of chemical in some extent, and the resistance would be contributed in the survival of $A$. womers leyi in the inside-spraying plot.

Kawai ${ }^{8)}$ noted that the ecosystem of tea fields is the most complex and the most stable agroecosystem in Japan. Leaves of tea plants grow thick beneath the plucking surface. Since the thick leaf layer blocks the penetration of chemicals inside the bush ${ }^{1)}$, the effects of insecticides are limited in the part of the bush below the plucking surface. The part of the bush below the plucking surface is very important as a refuge for natural enemies. The conservation and utilization of indigenous 
natural enemies that live inside bushes are important for integrated pest management of tea cultivation in Japan.

\section{REFERENCES}

1) Kawai, A, K. Kohata and Y. YAMAGUCHI (1999) : Deposition of chemicals on various parts of tea bushes sprayed on the plucking surface. Appl. Entomol. Zool. 34, 387-389.

2) Hamamura, T. (1985): The role of insecticide-resistant Amblyseius longispinosus in tea fields. Shokubutsu Boeki (Plant Protection) 21, 121-201 (In Japanese).

3) Nagatomo, S., N. Atari, T. Onimaru and T. NONAKA (1991): Studies on the control of Kanzawa spider mite, Tetranychus kanzawai KISHIDA, by the predacious mite, Amblyseius longispinosus (Evans) in tea fields. Bull. Kagoshima Tea Exp. Stn., 7, 1-76 (In Japanese with English summary).

4) Ohtani, T., A. Takafuji and M. INOUE (1991): Occurrence of Tetranychus kanzawai KISHIDA and its predators in an eggplant field sprayed with three synthtic pyrethroids. Jpn. J. Appl. Entomol. Zool. 35, 153-159.

5) Hamamura, T. (1986): Studies on the biological control of Kanzawa spider mite, Tetranychus kanzawai KISHIDA by the chemical resistant predacious mite, Amblyseius longispinosus (Evans) in tea fields. Bull. Natl. Res. Inst. Tea. 21, 121-201 (In Japanese with English summary).

6) Mochizuki, M. (1990): A strain of the predatory mite Amblyseius longispinosus (EvANS) resistant to permethrin, developing in the tea plantation of Shizuoka Prefecture (Acarina: Phytoseiidae). Jpn. J. Appl. Entomol. Zool., 34, 171-174 (In Japanese with English summary).

7) Mochizuki, M. (1994): Variations in insecticide susceptibility of the predatory mite Amblyseius womersleyi ScHICHA (Acarina: Phytoseiidae) in the tea fields of Japan. Appl. Entomol. Zool., 29, 203-209.

8) KAWAI, A. (1997): Prospect for integrated pest management in tea cultivation in Japan. JARQ, 31, 213-217. 


\section{茶株の内部と摘採面上から散布した農薬のケナガカブリダニ とカンザワハダニの個体数に及ぼす影響}

\section{独立行政法人 農業技術研究機構 野菜茶業研究所*}

河合章

摘

要

茶株の摘採面上からと樹冠内部に散布した 農薬の、捕食者ケナガカブリダニとその餌で あるカンザワハダニの個体数に及ほす影響を 検討した。1997年の4月から11月にかけて両 種の密度を調べ、その間に 6 回の薬剤散布を 行った。摘採面上から散布した区では、両種 の密度とも無散布区と差がなかった。摘採面 上からととともに樹冠内部にも散布した区で は、カンザワハダニの密度は無散布区に比べ

有意に高くなった。しかし、この区でもケナ ガカブリダニはカンザワハダニの密度を抑制 した。摘採面上から散布した農薬はケナガカ ブリダニに大きな影響を及仿さなかったが、 樹冠内部に散布した農薬の影響は大きかっ た。樹冠は摘採面上から散布された農楽の内 部への到達量を減少させており、樹冠内部は 天敵の保護場所として重要である。 